Tropical Journal of Pharmaceutical Research March 2016; 15 (3): 461-467

ISSN: $1596-5996$ (print); 1596-9827 (electronic)

(C) Pharmacotherapy Group, Faculty of Pharmacy, University of Benin, Benin City, 300001 Nigeria.

All rights reserved.

Available online at http://www.tjpr.org

Original Research Article

http://dx.doi.org/10.4314/tjpr.v15i3.5

\title{
Effect of Probiotics on Serum Biochemical and Blood Constituents in Chicken Challenged with Salmonella enterica Subsp Typhimurium
}

\author{
Alaeldein M Abudabos*, Mutee A Murshed, Mohammed M Qaid and \\ Abdelrahman G Abdelrahman \\ Department of Animal Production, College of Food and Agriculture Sciences, King Saud University, Riyadh, Saudi Arabia
}

*For correspondence: Email: alabudabos@gmail.com; Tel: 00966597634578 ; Fax: 0096614678474

Received: 1 October 2015

Revised accepted: 29 December 2015

\begin{abstract}
Purpose: To examine the effects of two commercial probiotics (Toyocerin and CloSTAT) on serum enzyme activities, and hematological and biochemical indices of broiler chickens challenged with Salmonella enterica serovars Typhimurium (ST).

Methods: The chicks received one of the following treatments at 0 day of age: $T 1=$ control group, unmedicated diet, unchallenged birds, (negative control); T2 = unmedicated diet + bacterial challenge (positive control); T3 = medicated diet with neoxyval $(0.05 \mathrm{~g} / \mathrm{kg}$ diet) + bacterial challenge (NEOX); T4 = toyocerin (1 g/kg diet) + bacterial challenge (Toyocerin); and T5 = CloSTAT (1 g/kg diet) + bacterial challenge (COLS). Blood samples were withdrawn from 7 selected chicks in each treatment at 7, 21, 28, 35 and 42 days of age, and analyzed for total protein, albumin and globulin concentration, and the albumin: globulin ratio computed. Glutamate-oxaloacetate transaminase (GOT) and glutatamate pyruvate transaminase (GPT) levels in serum were measured on days 7 and 42.

Results: The results revealed that albumin $(p<0.001)$, globulin $(p<0.001)$ and albumin: globulin ratio $(p<0.001)$ were influenced by the time of blood collection. Globulin increased significantly after ST challenge while albumin decreased significantly. Glutamate-oxaloacetate transaminase (GOT) after ST challenge was affected by treatment $(p<0.05)$. Higher levels were obtained from birds which had received NEOX or positive control, compared to negative control group.

Conclusion: Salmonella challenge affects serum albumin, globulin and GOT enzyme. The results obtained suggest that the probiotic, Toyocerin, mitigates the negative effects of Salmonella challenge.
\end{abstract}

Keywords: Bacillus subtilis PB6, Bacillus Cereus var. toyoi, Probiotics, Liver enzymes, Hematology, Salmonella enterica

Tropical Journal of Pharmaceutical Research is indexed by Science Citation Index (SciSearch), Scopus, International Pharmaceutical Abstract, Chemical Abstracts, Embase, Index Copernicus, EBSCO, African Index Medicus, JournalSeek, Journal Citation Reports/Science Edition, Directory of Open Access Journals (DOAJ), African Journal Online, Bioline International, Open-J-Gate and Pharmacy Abstracts

\section{INTRODUCTION}

Salmonella enterica serovars typhimurium (ST) is an enteric bacterium that can colonize chickens; it is a common serovar causing salmonellosis in broiler chickens $[1,2]$. The extent of Salmonella infection after oral inoculation can be systemic and often comprises infection of the liver [3].
After oral inoculation of adult Leghorn hens with doses of 109 cells of Salmonella enteritidis, it was recovered from $53 \%$ of liver samples after 5-weeks post-inoculation [4].

A significant decline in growth performance was reported in broilers as a result of Salmonella $[5,6]$. The reduction in performance was ascribed 
to decrease in feed intake in broilers due to mucosal damage, diarrhea and systemic infection [7,8]. The liver is one of the main systemic organs affected by Salmonella and as a result of damaged liver cells, liver enzymes increase in the blood.

Currently, probiotics are used in the poultry industry as an alternative to antimicrobial growth promoters [9]. Probiotics have been reported to prevent the colonization of the gut by pathogenic bacteria like Clostridium perfringens and Salmonella through the mechanism of competitive exclusion [9,10]. Bacillus subtilis is capable of producing an antimicrobial factor against many bacteria [11]. Other reports showed that Bacillus cereus var. toyoi based probiotics reduced the prevalence of Salmonella in poultry [12]. There is scarcity of information on the effects of probiotics on serum hematological, biochemical indices and liver enzymes activity in broiler chickens challenged with oral salmonella. Therefore, in the present study, the objective was to evaluate the effect of two strains of probiotics (Bacillus subtilis PB6 and Bacillus cereus var. toyoi) on hematological and biochemical indices of ST challenged broiler chickens.

\section{EXPERIMENTAL}

\section{Animals, husbandry and treatment}

The study was conducted under a protocol approved by King Saud University and complies with the current laws of Saudi Arabia. The experiment was carried out from 0 to 42 days of age by utilizing a total of two hundred, Cobb 500 broiler chicks which were allotted into 50 experimental cages with four chicks per cage. The chicks had been vaccinated for Marek's disease, Newcastle and infectious bronchitis. Feed and water were provided ad libitum and the birds were maintained at $24 \mathrm{~h}$ light schedule. $\mathrm{A}$ typical isocaloric and isonitrogenous starter $(0$ $14 \mathrm{~d}$ ) and finisher (15 - 42 d) diets based on corn-soybean meal diets were formulated in mashed form which met or exceed the recommendations in commercial practice (Tables 1, 2 and 3).

Chicks received the dietary treatments at 0 day of age as follows: $\mathrm{T} 1=$ control group, unmedicated diet, unchallenged birds, (negative control); T2 = unmedicated diet + ST (positive control); T3 = medicated diet with neoxyval $(0.05$ $\mathrm{g} / \mathrm{kg}$ diet) + ST (NEOX);

Table 1: Dietary ingredients and chemical composition of starter diets ( 0 to 14 days)

\begin{tabular}{|c|c|c|c|c|}
\hline Ingredient (\%) & $\mathrm{T} 1, \mathrm{T2}^{*}$ & T3* & $T 4^{*}$ & $\mathrm{~T}^{*}{ }^{*}$ \\
\hline Corn & 63.01 & 63.01 & 62.91 & 62.91 \\
\hline Soybean meal & 31.15 & 31.15 & 31.15 & 31.15 \\
\hline Palm oil & 1.72 & 1.72 & 1.72 & 1.72 \\
\hline Dicalcium phosphate & 1.96 & 1.96 & 1.96 & 1.96 \\
\hline Limestone & 0.73 & 0.73 & 0.73 & 0.73 \\
\hline Salt & 0.25 & 0.25 & 0.25 & 0.25 \\
\hline VM Mix ${ }^{1}$ & 0.5 & 0.5 & 0.5 & 0.5 \\
\hline DL-Methionine & 0.25 & 0.25 & 0.25 & 0.25 \\
\hline Lysine-HCL & 0.18 & 0.18 & 0.18 & 0.18 \\
\hline Threonine & 0.07 & 0.07 & 0.07 & 0.07 \\
\hline Sodium bicarbonate & 0.12 & 0.12 & 0.12 & 0.12 \\
\hline Choline chloride & 0.05 & 0.05 & 0.05 & 0.05 \\
\hline Neoxyval & 0 & 0.005 & 0 & 0 \\
\hline Toyocerin & 0 & 0 & 0.1 & 0 \\
\hline Clostat & 0 & 0 & 0 & 0.1 \\
\hline Total & 100 & 100 & 100 & 100 \\
\hline
\end{tabular}

${ }^{1}$ Vitamin-mineral premix contains in the following per kg: vitamin A, $2400000 \mathrm{IU}$; vitamin D, $1000000 \mathrm{IU}$; vitamin E, $16000 \mathrm{IU}$; vitamin K, $800 \mathrm{mg}$; vitamin $B 1,600 \mathrm{mg}$; vitamin $B_{2}, 1600 \mathrm{mg}$; vitamin $B_{6}, 1000 \mathrm{mg}$; vitamin $B_{12}, 6 \mathrm{mg}$; niacin, $8000 \mathrm{mg}$; folic acid, $400 \mathrm{mg}$; pantothenic acid, $3000 \mathrm{mg}$; biotin $40 \mathrm{mg}$; antioxidant, $3000 \mathrm{mg}$; cobalt, $80 \mathrm{mg}$; copper, $2000 \mathrm{mg}$; iodine, 400; iron, $1200 \mathrm{mg}$; manganese, $18000 \mathrm{mg}$; selenium, $60 \mathrm{mg}$, and zinc, $14000 \mathrm{mg}$; $T 1=$ control group, unmedicated diet, unchallenged birds, (negative control); T2=unmedicated diet + bacterial challenge (positive control); T3=medicated diet with neoxyval (0.05 g/kg diet) + bacterial challenge (NEOX); T4= toyocerin (1 $\mathrm{g} / \mathrm{kg}$ diet) + bacterial challenge (TOYO); and T5=CloSTAT (1 $\mathrm{g} / \mathrm{kg}$ diet) + bacterial challenge (COLS) 
Table 2: Dietary ingredients and chemical composition of finisher diets (15 to 35 days)

\begin{tabular}{lcccc}
\hline Ingredient (\%) & T1, T2 & T3 & T4 & T5 \\
\hline Corn & 70.09 & 70.09 & 69.99 & 69.99 \\
Soybean meal & 23.08 & 23.08 & 23.08 & 23.08 \\
Palm oil & 2.98 & 2.98 & 2.98 & 2.98 \\
Dicalcium phosphate & 1.87 & 1.87 & 1.87 & 1.87 \\
Limestone & 0.59 & 0.59 & 0.59 & 0.59 \\
Salt & 0.25 & 0.25 & 0.25 & 0.25 \\
VM Mix & 0.5 & 0.5 & 0.5 & 0.50 \\
DL-Methionine & 0.25 & 0.25 & 0.25 & 0.25 \\
Lysine-HCL & 0.17 & 0.17 & 0.17 & 0.17 \\
Threonine & 0.07 & 0.07 & 0.07 & 0.07 \\
Sodium bicarbonate & 0.11 & 0.11 & 0.11 & 0.11 \\
Choline chloride & 0.04 & 0.04 & 0.04 & 0.04 \\
Neoxyval & 0 & 0.005 & 0.005 & 0 \\
Toyocerin & 0 & 0 & 0.1 & 0 \\
Clostat & 0 & 0 & 0 & 0.1 \\
\hline Total & 100 & 100 & 100 & 100 \\
\hline
\end{tabular}

${ }^{1}$ Same as in the starter diet (Table 1)

Table 3: Chemical composition of the diets

\begin{tabular}{llc}
\hline Composition & $\begin{array}{l}\mathbf{0} \text { to } \mathbf{1 4} \\
\text { days }\end{array}$ & $\begin{array}{c}\mathbf{1 5} \text { to } \mathbf{3 5} \\
\text { days }\end{array}$ \\
\hline ME, kcal/kg & 3000 & 3150 \\
Crude protein, \% & 20.5 & 17.28 \\
Methionine, \% & 0.55 & 0.51 \\
Lysine, \% & 1.20 & 0.98 \\
Sulfur amino acids, \% & 0.89 & 0.80 \\
Threonine, \% & 0.85 & 0.73 \\
Calcium, \% & 0.95 & 0.85 \\
Phosphorus, \% & 0.41 & 0.38 \\
\hline
\end{tabular}

$\mathrm{T} 4$ = toyocerin $(1 \mathrm{~g} / \mathrm{kg}$ diet $)+\mathrm{ST}$ (TOYO); and T5 $=$ CloSTAT (1 g/kg diet) + ST (COLS). Neoxyval® (Sogeval Laboratory, France) was used as the reference antibiotic; each $1 \mathrm{~g}$ of the antibiotic contains $200 \mathrm{mg}$ oxytetracycline $\AA$ and $200 \mathrm{mg}$ neomycin ${ }^{\circledR}$. Toyocerin $\AA$ is a product with an active ingredient consists of viable spores of a microorganism: Bacillus cereus var. toyoi (Rubinum, Spain). CloSTATTM is a probiotics which contains a unique strain of Bacillus subtilis PB6 (CloSTAT, Kemin Industries Inc., Des Moines, IA).

\section{Challenge inoculum}

At day 16 of age, chicks in treatments 2 to 5 were challenged with ST $\left(3 \times 10^{9} \mathrm{CFU} / \mathrm{ml}\right)$. The strain used in this experiment was Salmonella typhimurium ATCC13311. Chicks were gavaged with $1 \mathrm{ml}$ of cocktail containing $3 \times 10^{9} \mathrm{CFU} / \mathrm{mL}$ ST which was obtained commercially (MicroBiologics, Cloud, MN-U.S.A) according to the procedure described by [6].

\section{Hematological measurements}

and

biochemical

The following analyses were conducted by using enzymatic colorimetric kits: total protein (Biuret method), albumin (Bromoreesol green method), globulin concentration was calculated, thereafter, as the difference between total protein and albumin concentrations. Albumin: globulin ratio was calculated. Seven chicks per group were selected for blood collection via brachial venipuncture into plain tubes for serological analysis starting at days 7 (before bacterial challenge), 21, 28, 35 and 42 (after the challenge). Samples were centrifuged by using plain tubes at $5{ }^{\circ} \mathrm{C}$ and $3,000 \mathrm{rpm}$ for $10 \mathrm{~min}$. Serum samples were stored in eppendorf tubes and stored at $-80{ }^{\circ} \mathrm{C}$ until further analysis, unless fresh sample is required for the analysis.

The activities of glutamate-oxaloacetate transaminase (GOT) and glutatamate pyruvate transaminase (GPT) in the serum were measured according to the colorimetric method by using GOT-GPT assay kits, Asan Pharmaceutical). For this purpose blood samples were withdrawn from 7 selected chicks of each treatment at days 7 (before bacterial challenge) and 42 (after the challenge).

At the end of the trial, blood samples were withdrawn from 5 selected chicks of each treatment via brachial venipuncture into EDTA tubes for hematological analysis and were placed inside an ice box and transferred to the laboratory. Within $1 \mathrm{~h}$ after collection, the hematological parameters were determined (Maxcom Auto Hematology Analyzer (MC-6200, China.

\section{Statistical analysis}

Data were analyzed by using the general linear model procedure of SAS [13]. Five treatments were arranged in 10 replications in a randomized complete block design. Means of measurements 
showing significant differences in analysis of variance (ANOVA) were tested using the difftype statement (PDIFF). Overall level for statistical significance was set at $p<0.05$. All values are expressed as statistical means \pm standard error of the mean (SEM).

\section{RESULTS}

The data related to serum biochemical indices are shown in Table 4. Total protein, albumin, globulin, and albumin : globulin ratio (A/G ratio) were similar among all groups $(p>0.05)$. The interaction term (treatment*week) was not significant for any parameters measured for serum biochemistry $(p>0.05)$.

On the other hand, albumin, globulin and their ratio (A/G ratio) were influenced by time of collection (week) $(p<0.001)$. Albumin concentration was the lowest when measured after the challenge $(1.13 \mathrm{~g} / \mathrm{dl}$ for week 3$)$, then albumin concentration the uttermost at weeks five and six (1.94, $194 \mathrm{~g} / \mathrm{dll}$, respectively). In the contrary, globulin concentration increased right after the challenge $(0.89 \mathrm{vs}$. $1.58 \mathrm{~g} / \mathrm{dl}$, for weeks one and three, respectively) and then started to decline after week four. On weeks five and six, the values were similar to the value before the challenge in week one $(0.72,0.75$ and $0.89 \mathrm{~g} / \mathrm{dl}$, respectively). The $A / G$ ratio dropped significantly after the challenge from 3.02 in week one to 0.87 in week three. In weeks five and six, $A / G$ ratio was not different from week one.

The activities of glutamate-oxaloacetate transaminase (GOT) and glutatamate pyruvate transaminase in the serum are presented in Table 5. Treatment showed no effect on GOT or GPT in serum before the challenge (week one) $(p>0.05)$. However, after the challenge (week 6 ), serum from birds which had received NEOX or positive control had significantly higher GOT value as compared to negative control (274.4, 244.6 and $195.6 \mathrm{IU} / \mathrm{L}$, for NEOX, positive and negative control, respectively) $(p<0.05)$. GOT for birds which had received CLOS was 230.6 IU/L. The lowest GOT value was obtained from birds which had received the negative control or TOYO (195.6 and $200.4 \mathrm{lU} / \mathrm{L}$, respectively). On the other hand, week of collection showed a significant effect on GOT $(p<0.01)$, the mean for GOT in week six was $229 \mathrm{IU} / \mathrm{L}$ as compared to $199 \mathrm{IU} / \mathrm{L}$ in week one. In this study, the GPT values after the challenge were not affected by any treatments $(p>0.05)$.

Table 6 shows the effect of treatment on hematological parameters of broiler blood profile. The values of the blood parameters measured in this trial were comparable and treatment had no effect on blood hematological values $(p>0.05)$.

Table 4: Serum biochemical profile of broilers

\begin{tabular}{|c|c|c|c|c|c|}
\hline Treatment & Challenge & $\begin{array}{c}\text { Total protein } \\
(\mathrm{g} / \mathrm{dl})\end{array}$ & $\begin{array}{c}\text { Albumin } \\
(\mathrm{g} / \mathrm{dl})\end{array}$ & $\begin{array}{c}\text { Globulin } \\
(\mathrm{g} / \mathrm{dl})\end{array}$ & A/G ratio \\
\hline Negative control & No & 2.73 & 1.62 & 1.11 & 2.43 \\
\hline Positive control & Yes & 2.86 & 1.72 & 1.13 & 1.93 \\
\hline Neoxyval® & Yes & 2.79 & 1.70 & 1.09 & 2.29 \\
\hline Toyocerine® & Yes & 2.57 & 1.63 & 0.94 & 2.4 \\
\hline Clostat $\AA$ & Yes & 2.76 & 1.58 & 1.19 & 2.02 \\
\hline SEM \pm & & 0.13 & 0.05 & 0.12 & 0.24 \\
\hline$P$ value & & ns & ns & ns & ns \\
\hline Age (weeks) & \multicolumn{2}{|c|}{ Challenge } & & & \\
\hline 1 & No & 2.68 & $1.78^{\mathrm{D}}$ & $0.89^{D}$ & $3.02^{a}$ \\
\hline 3 & Yes & $\begin{array}{l}2.00 \\
2.71\end{array}$ & $1.13^{\mathrm{d}}$ & $1.59^{\mathrm{a}}$ & $0.87^{b}$ \\
\hline 4 & Yes & 2.96 & $1.46^{\mathrm{C}}$ & $1.52^{\mathrm{a}}$ & $1.21^{\mathrm{b}}$ \\
\hline 5 & Yes & 2.77 & $1.94^{\mathrm{a}}$ & $0.72^{\mathrm{b}}$ & $3.35^{\mathrm{a}}$ \\
\hline 6 & Yes & 2.69 & $1.94^{\mathrm{a}}$ & $0.75^{\mathrm{D}}$ & $3.20^{\mathrm{a}}$ \\
\hline SEM & & 0.11 & 0.04 & 0.11 & 0.19 \\
\hline$p$ value & & ns & $* * *$ & $* * *$ & $* * *$ \\
\hline Treatment*Week & & ns & ns & ns & ns \\
\hline
\end{tabular}

For treatment, each mean is based on 35 birds. For week, each treatment is based on 7 birds. ${ }^{\text {ab }}$ Means in the column with different superscripts differ significantly, ${ }^{* * *} p<0.001$ 
Table 5: The concentration of hepatic enzymes in serum before and after the bacterial challenge

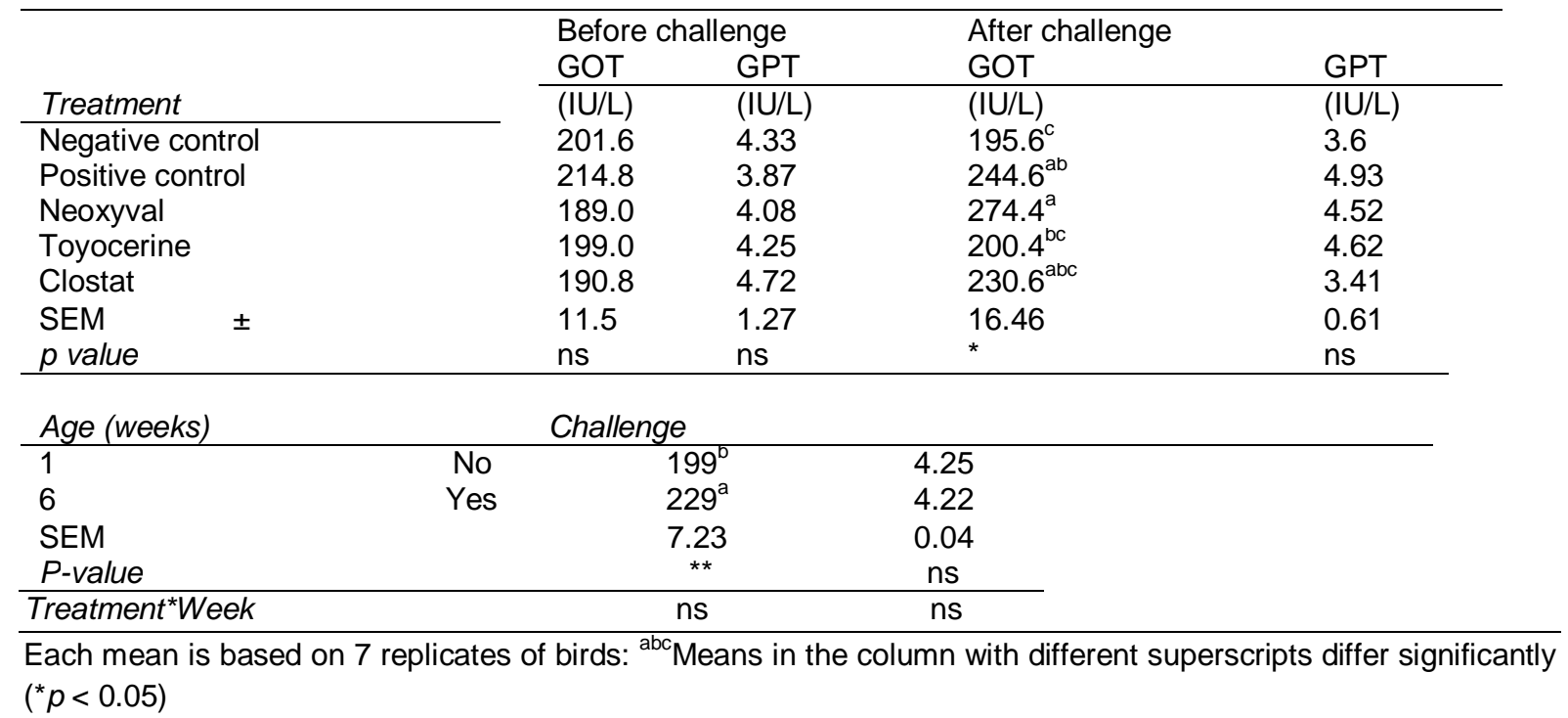

Table 6: Effect of different treatments on blood hematology

\begin{tabular}{|c|c|c|c|c|c|c|c|}
\hline Parameter & Control & Negative & Neoxyval & Toyocerine & Clostat & SEM & P-value \\
\hline WBC $\left(\times 10^{9} / I\right)$ & 111.8 & 110.9 & 114.1 & 113.7 & 109.1 & 2.99 & $\mathrm{~ns}$ \\
\hline $\operatorname{RBC}\left(\times 10^{12} / \mathrm{l}\right)$ & 4.39 & 4.61 & 4.4 & 4.6 & 4.9 & 0.18 & ns \\
\hline HGB $(g / d l)$ & 40.8 & 40.9 & 39.3 & 40.8 & 41.7 & 1.09 & ns \\
\hline $\operatorname{MCV}(\mathrm{fl})$ & 113.7 & 114 & 111.6 & 111.5 & 114.1 & 1.59 & ns \\
\hline $\mathrm{MCH}(\mathrm{pg})$ & 92.9 & 88.9 & 89.7 & 89.7 & 84.7 & 2.23 & ns \\
\hline $\mathrm{MCHC}(\mathrm{g} / \mathrm{dl})$ & 81.7 & 78 & 80.4 & 80.4 & 74.2 & 2.17 & ns \\
\hline RDW-CV (\%) & 9.7 & 10.1 & 9.7 & 10.4 & 9.9 & 0.35 & ns \\
\hline RDW-CD (fl) & 44.6 & 46.2 & 43.6 & 46.6 & 45.6 & 1.96 & ns \\
\hline $\mathrm{HCT}(\%)$ & 49.9 & 52.5 & 49.1 & 50.9 & 56.6 & 2.13 & ns \\
\hline $\operatorname{PLT}\left(\times 10^{y} / I\right)$ & 31.2 & 33.2 & 36.8 & 32.8 & 44.6 & 5.44 & ns \\
\hline $\operatorname{MPV}(\mathrm{fl})$ & 11.6 & 11.5 & 11.4 & 11.6 & 11.6 & 0.24 & ns \\
\hline PDW & 12.0 & 12.01 & 11.8 & 13.7 & 16.3 & 1.71 & ns \\
\hline PCT (\%) & 0.036 & 0.038 & 0.041 & 0.038 & 0.051 & 0.006 & ns \\
\hline
\end{tabular}

WBC: white blood cell counts, RBC: total red blood cell counts, HGB: hemoglobin content, MCV: mean corpuscular volume, $\mathrm{MCH}$ : mean corpuscular hemoglobin, $\mathrm{MCHC}$ : mean corpuscular hemoglobin concentration, RDW-SD: standard deviation in red cell distribution width, RDW-CV: coefficient variation of red cell distribution width, HCT: hematocrit, PLT: platelet count, MPV: mean platelet volume, PDW: platelet distribution width, PCT: plateletcrit

\section{DISCUSSION}

The data related to serum biochemical indices indicated no differences between treatments in total protein, albumin, globulin, and $A / G$ ratio among all groups. The findings of this trial are in agreement to the findings of [14] who reported no significant differences in serum biochemical indices examined as a result of probiotic supplementation.

The activities of glutamate-oxaloacetate transaminase (GOT) and glutatamate pyruvate transaminase in the serum were not affected by treatment before the bacterial challenge. However, after the challenge higher GOT values were found in birds which had received NEOX or positive control while probiotics lowered the GOT value especially for TOYO group. This finding agrees with [15] who reported that colonization of Salmonella in organs increases the liver enzyme activities in blood. Several studies have assessed the effects of Salmonella on the gene expression of chicken immune tissues or cells $[16,17]$. It was reported that the effects of Salmonella infection on the liver transcriptome profiles of broilers reflect a predominance of down regulation of genes with cell cycle and metabolic functions [18]. A clear sign of hepatic damage is the leaking of cellular enzymes into the plasma [19].

The values of the hematological parameters of broiler blood profile were comparable and treatment had no effect on blood hematological 
values. Similar to our findings, it was reported that probiotics did not show any harmful changes on blood hematological parameters and it could improve health condition by enhancing concentration of hemoglobin, hematocrit and red blood cell count in broilers [20]. Conversely, probiotics lowered lymphocytes and neutrophil values when compared to the control [21].

\section{CONCLUSION}

Neither challenge nor treatment has a significant impact on blood hematological values. Albumin, globulin and their ratio (A/G ratio) were influenced by time of collection. Albumin concentration was lowest when measured after the challenge. On the contrary, globulin concentration increased right after the challenge. The results from this study suggest that the probiotic, TOYO, alleviates the negative effects of Salmonella challenge.

\section{ACKNOWLEDGEMENT}

The authors would like to extend their sincere appreciation to the Deanship of Scientific Research at King Saud University for its funding of this research through Research Group Project no. RGP-VPP-273.

\section{REFERENCES}

1. Ribeiro AML, Vogt LK, Canal CW, Cardoso MR, Labres $R V$, Streck AF, Bessa MC. Effects of prebiotics and probiotics on the colonization and immune response of broiler chickens challenged with Salmonella Enteritidis. Braz J Poult Sci 2007; 9(3): 193-200.

2. Van Immerseel F, De Zutter L, Houf K, Pasmans F, Haeseb rouck $F$, Ducatelle $R$. Strategies to control Salmonella in the broiler production chain. World's Poult Sci J 2009; 65: 367-391.

3. Rocha TM, Andrade MA, Gonzales E, Stringhini JH, Santana ES, Pôrto RNG, Minafra-Rezende CS. Liver function and bacteriology of organs in broiler inoculated with nalidixic acid-resistant Salmonella Typhimurium and treated with organic acids. Ital J Anim Sci 2013; 12(3): 374-352.

4. Gast RK, Beard CW. Serological detection of experimental Salmonella enteritidis infections in laying hens. Avian Dis 1990; 5: 721-728.

5. Marcq C, Cox E Szalo IM, Théwis A, Beckers $Y$. Salmonella Typhimurium oral challenge model in mature broilers: Bacteriological, immunological, and growth performance aspects. Poult Sci 2011; 90: 59-67.

6. Abudabos AM, Yehia HM, Alotybi MN, Garelnabi AR, Alyemni AH. Effects of direct-fed microbial on broiler performance and susceptibility to oral salmonella enteritidis challenge. J Food Agric Environ 2014; 12 (2): 30-34.

7. Cardinale E, Gros-Claude JDP, Rivoal K, Rose V, Tall F, Mead GC, Salvat G. Epidemiological analysis of Salmonella enterica spp. enterica serovars Hadar, Brancaster and Enteritidis from humans and broiler chickens in Senegal using pulsed-field gel electrophoresis and antibiotic susceptibility. J Appl Microbiol 2005; 99: 968-977.

8. Vandeplas $S$, Dubois R, Thiry $C$, Beckers $Y$, Welling GW, Thonart $P$, Théwis A. Efficiency of a Lactobacillus plantarum-xylanase combination on growth performances, microflora populations, and nutrient digestibilities of broilers infected with Salmonella Typhimurium. Poult Sci 2009; 88: 1643-1654.

9. Teo AYL, Tan HM. Evaluation of the performance and Intestinal gut microflora of broilers fed on corn-soy diets supplemented with Bacillus subtilis PB6 (CloSTAT). J Appl Poult Res 2007; 16: 296-303

10. Abudabos A, Alyemni A, Al Marshad BA. Bacillus subtilis PB6 based-probiotic (CloSTATTM) improves intestinal morphological and microbiological status of broiler chickens under Clostridium Perfringens challenge. Int J Agric Biol 2013; 15(6): 978-982.

11. Yurong $Y$, Ruiping S, Shimin Z, Yibao J. Effect of probiotics on intestinal mucosal immunity and ultrastructure of cecal tonsils of chickens. Arch Anim Nutr 2005; 59: 237-246.

12. Vilà $B$, Fontgibell A, Badiola I, Esteve-Garcia E, Jiménez G, Castillo M. Brufau J. Reduction of Salmonella enterica var. Enteritidis colonization and invasion by Bacillus cereus var. toyoi inclusion in poultry feeds. Poult Sci 2009; 88(5): 975-979.

13. SAS Institute Inc. SAS Users Guide: Statistics. Version 9.1.3. 2003; SAS Institute, Cary, NC, U.S.A.

14. Owosibo AO, Odetola OM, Odunsi OO, Adejinmi OO, Lawrence-Azua OO. Growth, haematology and serum biochemistry of broilers fed probiotics based diets. Afri J Agr Res 2013; 8(41) 5076-5081.

15. Fan S, Zheng J, Duan Z, Yang N, Xu G. The influences of SE infection on layers' production performance, egg quality and blood biochemical indicators. J Anim Sci Biotech 2014; 5(1): 4.

16. Zhou H, Lamont SJ. Global gene expression profile after Salmonella enterica Serovar enteritidis challenge in two F8 advanced intercross chicken lines. Cytogenet Genome Res 2007; 117: 131-138.

17. Ciraci C, Tuggle CK, Wannemuehler MJ, Nettleton D, Lamont SJ. Unique genome-wide transcriptome profiles of chicken macrophages exposed to Salmonella-derived endotoxin. Genomics 2010; 11: 545.

18. Coble DJ, Sandford EE, Ji T, Abernathy J, Fleming D, Zhou H, Lamont SJ. Impacts of Salmonella enteritidis infection on liver transcriptome in broilers. Genesis 2013; 51:357-364.

19. Schmidt E, Schmidt FW. Glutamate dehydrogenase. In: Bergmeyer U, Eds. Methods of enzymatic analysis. 3rd edn, New York: Academic Press; 1983; pp 216-217. 
Abudabos et al

20. Kokosharov T. Clinical and hematological effect of Salmonalla gallinarum endotoxin on cockrel. Vet Archiv 2002; 72: 269-276
21. Owosibo AO, Odetola OM, Odunsi OO, Adejinmi OO, Lawrence-Azua OO. Growth, haematology and serum biochemistry of broilers fed probiotics based diets. African J Agric Res 2013; 8(41): 5076-5081. 